\title{
ESTONIAN WORD PROSODY ON THE PROCRUSTEAN BED OF MORAE
}

\author{
Natalia Kuznetsova \\ Institute for Linguistic Studies, Russian Academy of Sciences, \\ and the University of Turin
}

\begin{abstract}
The paper analyses existing moraic conceptions of Estonian quantity. Main features of functional, generative and phonetically-instructed moraic accounts of Estonian are considered. In most generative accounts, morae simultaneously represent several layers of functionally and structurally diverse information. This brings along a considerable increase in formal analytical machinery and internal controversies. In a structural functional framework, morae can be used to formalise the prosodic contrast of long and short stressed syllables in Estonian. Its relevance is seen in actual functioning of the prosodic system. This contrast is built upon the segmental contrast of short and long phonemes and, in turn, serves as a basis for the contrast of two distinctive foot accents, light and heavy. As an example, a formal morphonological algorithm of calculating Estonian foot accents, which also shows the place of the syllable weight contrast, is proposed.
\end{abstract}

Keywords: Estonian, structural functional phonology, autosegmental phonology, word prosody, mora, quantity

DOI: https://doi.org/10.12697/jeful.2018.9.1.09

\section{Introduction}

Estonian phonology has been a subject of extensive research since the 1930s, which has progressed within three main frameworks: structuralist, generative, and the studies by phoneticians who have sought to formalise the results of phonetic experiments.

Structural functional analysis of Estonian during the 1960s and 1970s laid the basis for its current phonological understanding (Asu et al. 2016: 238), but now this paradigm is underrepresented in Estonian phonology. Most of research is conducted either within generative paradigms or in phonetics. However, its potential has not yet been fully exhausted. On the contrary, a functional and cognitive view on the language structure, when the latter is seen as a function of general 
processes of human communication and cognition, seems to be gaining popularity again, also in phonology. For example, paradigms represented by Mompéan-González (2014), Hall et al. (2018), and Kapatsinki (2018) are in the same line with those proposed in earlier functionalist works (e.g. Jakobson 1960, Kasevič 1983). Phonology in a structural functional paradigm is seen as one of the auxiliary levels helping to transmit a message and achieve efficient communication. Phonological structure and its dynamics are results of language use by human beings and therefore follow general cognitive mechanisms. The present paper aims at developing the functional-structural approach to Estonian phonology further, as well as at its critical comparison with other frameworks.

The main object of the present study is the mora in Estonian. It is an important notion for many accounts of Estonian phonology, discussed below, and is typically referred to as "one of what heavy syllables have two of" (Prince 1980: 525-526). A circular definition allows a very loose usage of the term. At the same time, the mora lies at the very core of formal representations, so it is extremely important to understand its real content in various accounts. The typological concept of the mora is addressed in Section 2, and existing moraic accounts of Estonian in Section 3. Section 4, contributes to the grounding of the functional-structural analysis of the Estonian morae, and Section 5 contains conclusions.

Any moraic account in Estonian relies on a certain conception of stress (both primary and secondary). There is still not a final consensus on stress placement rules among Estonian phonologists and phoneticians (cf. latest remarks in Hint 2001: 253-257, Pajusalu et al. 2005: 100, Asu and Lippus 2018). Estonian stress requires further phonetic and phonological investigation, so the very facts which form the basis for most moraic accounts of Estonian are still to be verified. This remark made, Estonian stress will be left aside here.

\section{The mora in linguistic typology}

\subsection{Functional structural approach of the Prague school}

The term mora ('duration of time, delay' in Greek) originally referred to the smallest rhythmic unit that permitted a description of stress rules in the poetic metrics of Ancient Greek and Latin; similar units were used in Sanskrit (mātrā) and Japanese (on).

Jakobson (1931/1962, 1937/1962) and Trubetzkoy (1935/1968, $1939 / 1969)$ introduced the term into linguistic typology. The former 
applied it to a distinction of pitch-accent types in certain languages. For Trubetzkoy, mono- vs. bimoraicity was a way to describe general prosodic homogeneity vs. heterogeneity of the syllable nucleus. Short syllable nuclei behave as a single prosodic domain, while the two parts of long syllable nuclei are "treated differently prosodically, the treatment of the difference being distinctive" (Trubetzkoy 1939/1969: 175). Several points of this conception (ibid.: 173-181) which have entailed major inconsistencies in later theoretic advances on the mora are summarised below.

(1) Trubetzkoy gives no clear list of relevant prosodic properties that might allow morae to be detected. He mentions stress and stød placement rules, contrasts of tones and pitch accents, and also prosodic equality between long vowels and polyphonematic diphthongs or combinations of a vowel and a consonant.

(2) The maximal number of morae in a syllable remains unclear. The contrast between long and short syllable nuclei is generally considered as logically privative, but three- and four-mora nuclei are assumed possible for tonal languages.

(3) The mora is an abstract phonological notion, but Trubetzkoy refers to its possible phonetic correlates, such as a longer physical duration or a presence of stød in long nuclei.

(4) The very nature of the mora raises questions. It is an analytical tool helping Trubetzkoy to describe the dual nature of syllable. The latter is a segmental phonotactic unit which consists of phonemes, but also a prosodic domain which carries word-prosodic units (Hyman 1985: 1). Trubetzkoy observed various possible correlations between the two functions of the syllable, and the mora notion allowed him to typologise those. However, the two roles of the syllable are not clearly distinguished by him. On the one hand, mono- vs. bimoraicity is claimed to be an abstract prosodic property of syllable nuclei; on the other hand, the mora is referred to as the smallest prosodic unit and a constituent of long syllable nuclei (Trubetzkoy 1939/1969: 170, 177, 182).

Trubetzkoy did not specify any exact relations between moraic, syllabic and segmental boundaries. He considered Estonian to be a mora-counting language, obviously on the same grounds as Saami (Lapp), where "long vowels occur only in the same environments as clearly biphonematic diphthongs". For such multiple length systems, he still admitted only a binary phonological contrast of mono- and bimoraic syllable nuclei (ibid: $180-181$ ). 


\subsection{Formalisation of the mora: metrical and autosegmental approaches}

Subsequent years saw an acute interest in syllable structure and a rise in research on African tonal languages (cf. Pike and Pike 1947, Kuryłowicz 1948). The term 'syllable weight' was coined by Allen (1965) and brought into general use by Newman (1972), who defined syllable weight as an intrinsic structural rather than a positional property of syllables.

Syllable weight was further formalised in two main directions, both of which used morae (viz. Fox 2000: 79-85). A metrical approach originated from studies on stress and an autosegmental one from those on tone. In both, weight became primarily a positional property of syllables. The mora, the weight unit, kept its dual nature as either a concrete part of the syllable or a way to measure its prosodic properties. Attempts to establish a formal prosodic hierarchy and clear correspondences between morae and segments aggravated the original opacity of the term rather than resolved it.

Within the metrical approach, Prince declared the mora an "immediate constituent of the [syllable] rime", notably in his study on Estonian quantity (Prince 1980: 526; see Fig. 1a). His metrical grid structure presumes that lower level units are constituents of higher level units. However, the statement that "long vowels have two moras, short vowels one" (Hayes 1989: 256, cf. Fig. 1c) implies that morae can be also constituents of vowels. In this case, the moraic level should be logically placed below the phonemic one. On the other hand, morae also represent the syllable's positional prosodic properties, because syllable weight is detected according to the word stress rules, etc. Morae formalise a link between syllables and higher hierarchic levels (foot/word). In this case, it would be logical to place the moraic tier over the syllabic one. Prince's metrical grid makes neither choice, as it places morae between syllables and segments. The same basic way of representation was maintained by Hyman (1985: 17, Fig. 1b, ' $x$ ' stands for mora) and Hayes (1989: 254, Fig. 1c; 1995) and became standard in moraic phonology. 

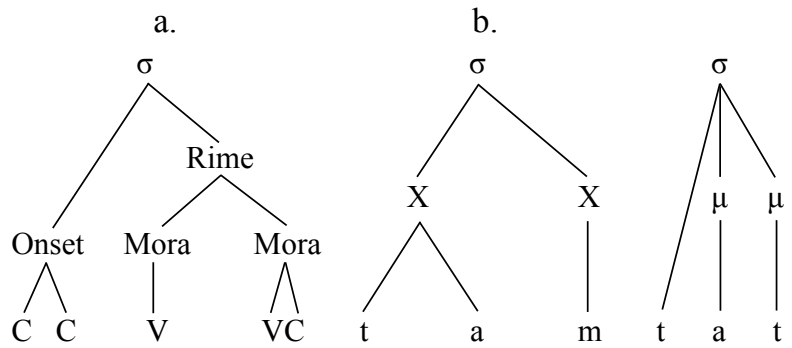

c.

Figure 1. Morae within a metrical stress grid by (a) Prince, (b) Hyman, (c) Hayes

An alternative representation of morae is their autosegmentalisation. This approach was first developed for tonal languages by Hyman, who claimed it "incompatible with the branching syllable structure" (Hyman 1985: 3). He followed Goldsmith (1976: 27-28), who distinguished between two independent layers of information realised simultaneously in the phonetic signal: sequences of segmental and suprasegmental units. None of these levels is subordinated to the other, they are just associated. Hyman (1985: 16; Fig. 2a) introduced the level of morae (X-tier) between segments and suprasegmentals for tone to formalise the rules of their association.

His moraic representation of stress, however, is not autosegmental, as it follows the metrical grid structure (Fig. 1b). A real autosegmentalisation for stress morae could look like that provided by Odden (1997: 175, Fig. 2b), where an X-tier shows segmental slots, and morae are placed above the syllable. The dual nature of the syllable as a domain for segmental grouping and a bearer of prosodic units can be clearly seen, if segmental and suprasegmental information is given separately. The necessity of autosegmentalising tone in formal representations became apparent to researchers early enough, but this is still not universally admitted for other kinds of lexical prosody, including suprasegmental quantity in Estonian (see below).

Hayes (1995: 299, Fig. 2c) also proposed a dual distinction of weight for languages in which CVC syllables can behave as light or heavy depending on the prosodic process they are involved in. However, both moraic tiers are still placed below the syllabic level, so the syllable weight is not autonomous from segmental composition. The relationship between the two moraic tiers is one of dependency rather than association. Fox (2000: 110, Fig. 2d) suggested a more autosegmental version 
of the dual distinction of weight, with the "foot quantity" level above the syllabic one. Seeing syllabic and segmental quantity as properties rather than constituents, he eventually placed the two outside a strictly-layered hierarchy of "true" units, as dependent tiers associated with the latter (ibid.: 111, Fig. 2e).

a.

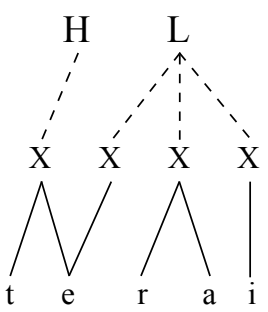

b.

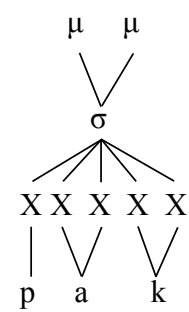

c.

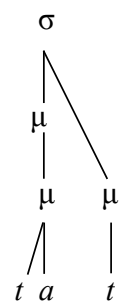

d.

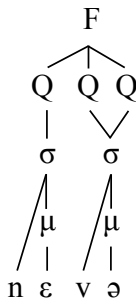

e.<smiles>OOPCl</smiles>

Figure 2. Autosegmentalisation of morae for (a) tone by Hyman and (b) stress by Odden; dual distinction of weight by (c) Hayes and $(\mathrm{d}, \mathrm{e})$ Fox

\subsection{Phoneticisation of the mora: mora-splitting}

The search for phonetic correlates of the mora became popular in the 1990 s, with a rapid growth in experimental phonetic studies. Moraic analysis was picked up by phoneticians after a mora-splitting procedure was introduced by Maddieson (1993: 14; Fig. 3) and promoted in Hubbard (1994), Broselow et al. (1997), and others. Maddieson (1993: 9) claimed that "moraic structure and duration show a general relationship". As surface durational contrasts often show a more complex structure than just a binary distinction, mora-splitting/sharing between segments was proposed to account for this.

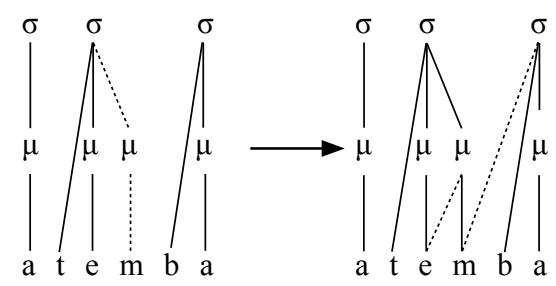

Figure 3. Mora splitting (Maddieson): /atemba/ > [ate' $\mathrm{m} \cdot \mathrm{ba}$ ] 
Notably, even the split morae are not able to cover all observed durational microvariability language-internally and cross-linguistically. It is admitted that morae do not need to reflect exact durations (e.g. Lehiste 1960: 51-52, Maddieson 1993: 9). On the other hand, on the road of mora-splitting there is not a natural border between cases where the moraic structure should still reflect this variability and where it should stop doing so. Therefore, some have even proposed to separate phonological weight from phonetic duration entirely (Erwin 1996, Gordon 2004).

Putting phonological morae in direct correspondence with duration is similar to an attempt to depict fine qualitative allophonic variability of segments in phonological transcription. The ineffectiveness of this idea for quantity might seem less obvious than for quality, because the former is often seen as an entirely suprasegmental feature. It is a paradox that a typical metrical grid at the same time de facto links quantity to segments. Any kind of quantity linearisation at just one hierarchical level fails to distinguish between various layers of linguistic information transmitted by the speech signal:

Length is not just a matter for segments; whatever higher units of prosodic structure we postulate, they have extent in time, and the temporal structure of utterances is a reflection of the timing relations present at the different levels within this structure... Furthermore, since timing relations at every level are manifested along a single dimension, time, the actual lengths of individual segments and syllables are the complex result of combining factors of different kinds (Fox 2000: 107-108).

Especially in such complex quantity systems like Estonian, a linearisation of an essentially non-linear structure brings along an everlasting battle with formalism, with always more sophisticated tricks used but results still far from satisfactory.

\section{Existing moraic analyses of Estonian}

\subsection{Main facts about Estonian stress and quantity}

Basic facts about Estonian stress, syllabic structure, segmental and suprasegmental quantity are given below. The phonological interpretation mainly follows structural analyses by Viitso $(1978,1979,2003)$, Eek (1986, 1990), and Hint (1973, 2001, 2015a, b). I have discussed it in detail elsewhere (Kuznetsova 2018) and here give a brief summary. 
The distinction of three quantities is phonetically realised within the disyllabic foot nucleus (a prosodically active sequence from the first syllable vowel throughout the second syllable vowel) ${ }^{1}$. The Estonian foot can contain from one to three syllables (cf. Lippus et al. 2013, Pajusalu 2015 for the latest overviews). In a monosyllabic foot, the foot nucleus is truncated, and there is only a binary segmental length contrast. The following quantitative proportions between the three key segments in the foot nucleus seem the most important factors in the production and perception of quantities (Eek and Meister 2004: 271):

$$
\begin{aligned}
& \text { Q1: } \sigma_{1} \text { nucleus } \quad<\sigma_{2} \text { nucleus } \\
& \text { Q2: } \sigma_{1} \text { nucleus } \geq \sigma_{1} \text { coda } \leq \sigma_{2} \text { nucleus } \\
& \text { Q3: } \sigma_{1} \text { nucleus }<\sigma_{1} \text { coda }>\sigma_{2} \text { nucleus }
\end{aligned}
$$

Authors'abbreviations: ' $\sigma_{1}$ nucleus' - a short vowel, the first part of a long vowel/ diphthong; ' $\sigma_{1}$ coda' - the last element of the 1st syllable (i.e. the second part of a long vowel/diphthong, the first consonant in a cluster, the first part of a geminate); ' $\sigma_{2}$ nucleus' - a 2nd syllable vowel.

Figure 4. Proportions between three key segments in the foot nucleus (Eek and Meister 2004: 271)

The surface ternary contrast contains two binary phonological contrasts. First, there is a segmental contrast of long vs. short vowels and fortis vs. lenis consonants. Second, there is a suprasegmental contrast of two foot accents: light /'/ and heavy $/ \%$ The foot accent is a lexicalised (morphologised) prosodic pattern of realisation of the foot nucleus.

Di- and trisyllabic feet in Q1 and Q2 phonologically differ only in their segmental content. The former starts with a short first syllable (open with a short vowel), and the latter with a long first syllable (closed and/or containing a long vowel or a diphthong), cf. types $2 \mathrm{a}$ vs. $2 \mathrm{~b}-\mathrm{f}$ in

1 A more conventional term for the foot nucleus would be e.g. minimal foot in Eek and Meister (1997) or just foot in most generative accounts (Prince 1980 etc.). However, the foot is understood here as "the formal vehicle for stress" (Odden 1997: 178), not as a structural unit. It starts with a stressed syllable and ends before the following stressed syllable. Unparsed syllables are permitted only at the beginning of a morphological word, if the first lexicalised stress falls on its second syllable (Viitso 2008: 183-184). The accent-bearer can be, however, shorter than the foot itself (it does not contain the first syllable onset, the coda of the second syllable and the whole third syllable). This prosodically active part of the foot is called the foot nucleus in the same way as syllable nucleus defines the prosodically active part of a syllable. 
Table 2. The feet in Q3, in turn, can have an identical phonemic structure to those in Q2 and contrast to the latter only prosodically, i.e. in accent, cf. types $2 \mathrm{~b}-\mathrm{f}$ vs. $3 \mathrm{a}-\mathrm{e}$ in Table 2 . All monosyllabic feet carry heavy accent (Table 2, 1a-e).

Estonian syllabic structure is important for a discussion of moraicity. Non-initial syllables will not be analysed in detail. There are in total five quantitative types of the first syllable nucleus in monosyllabic feet and six types in di- and trisyllabic feet (cf. Hint 2001, Viitso 2003, Eek and Meister 2004). Five of the latter six types can occur in feet under both accents, and one only under a light accent (see structures and examples for mono- and disyllabic feet in Tables 1 and 2).

Table 1. First syllable quantitative structure in mono-, di- and trisyllabic Estonian feet

\begin{tabular}{|c|c|c|c|c|c|}
\hline \multirow{2}{*}{\multicolumn{2}{|c|}{$\begin{array}{c}\text { Monosyllabic foot } \\
\text { Heavy accent } / \text { / }\end{array}$}} & \multicolumn{4}{|c|}{ Di- and trisyllabic feet } \\
\hline & & Light & cent /'/ & Heavy & ent $/ \%$ \\
\hline \multirow{3}{*}{\multicolumn{2}{|c|}{ 'VV }} & & 'V & & \\
\hline & & & 'V & 'VV & \\
\hline & & & 'VC & 'VC & \\
\hline \multirow[t]{4}{*}{$(\mathrm{C}(\mathrm{C}))$} & 'VCC & $(\mathrm{C}(\mathrm{C}))$ & 'VCC & 'VCC & $\mathrm{S}_{2}\left(\mathrm{~S}_{3}\right)$ \\
\hline & 'VVC & & 'VVC & 'VVC & \\
\hline & 'VVCC & & 'VVCC & 'VVCC & \\
\hline & 'VVCCC & & & & \\
\hline
\end{tabular}

Abbreviations: VV - a long vowel/diphthong; CC - a fortis consonant or a cluster; $(\mathrm{C}(\mathrm{C})$ ) - optional syllabic onsets; S2(S3) - presence of the 2nd and optionally the 3rd syllable in the foot.

Estonian stress contains two main distinctions important for phonology. First, the foot stress can be morphologically unbound or bound. In other words, there is a default foot-rhythmic stress and a lexicalised foot stress (see examples in Viitso 2003: 17). The distinction between rhythmic and lexicalised stresses was first made for Estonian by Hint (1973) and discussed at length in Viitso (1979), Eek (1986). Moreover, it finds robust grounding in modern typological works on stress and accent (van der Hulst 2010, 2014). Second, within a multifoot word, there can be primary and secondary foot stresses. 


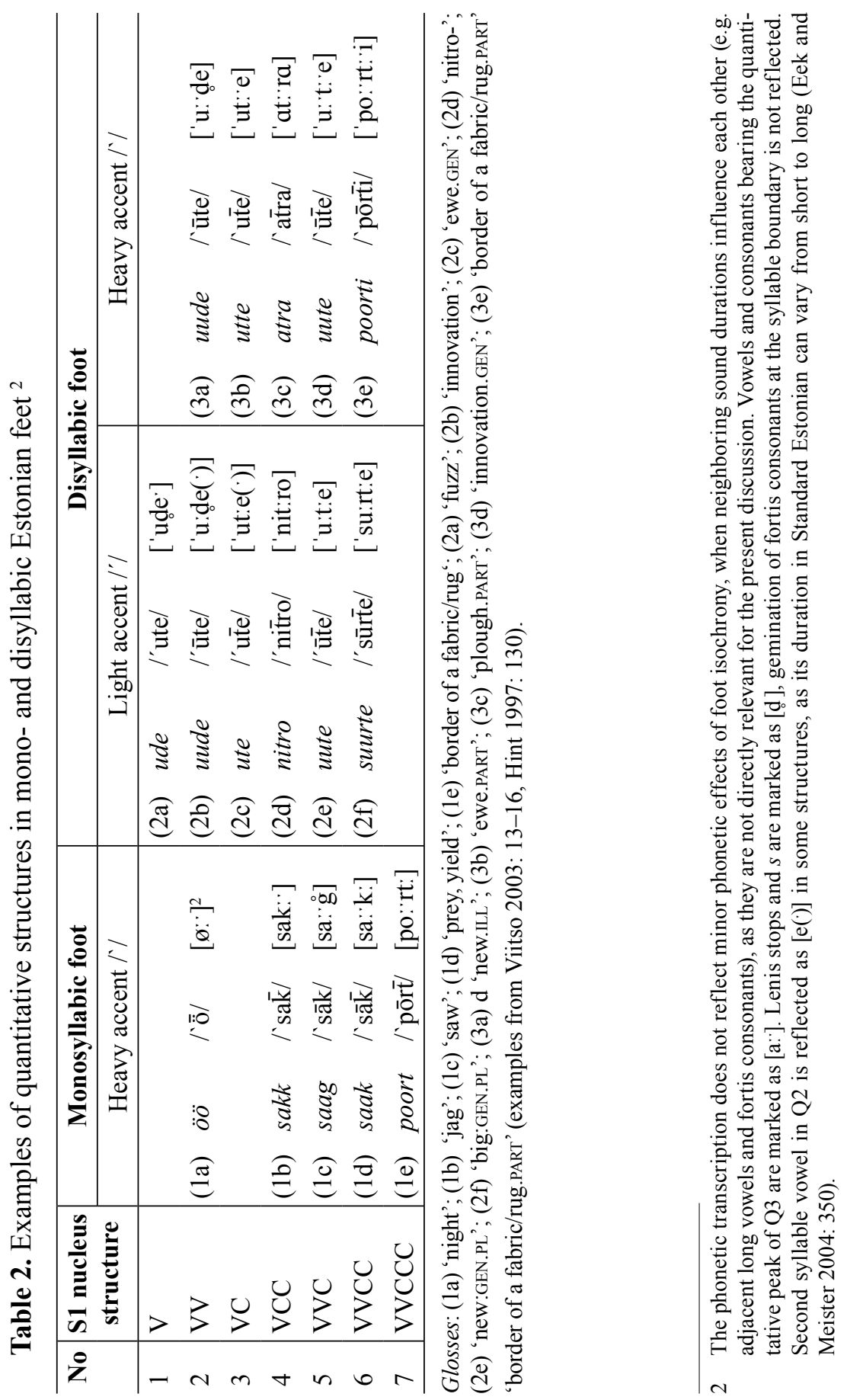


Rhythmic stress is always secondary and exhibits only the durational patterns Q1 and Q2, so no accentual contrasts. Lexicalised stress is linked to a given position in certain morphemes and cannot shift to another syllable. Besides, it is distinctive in a similar way to tone in tonal languages: it distinguishes between the light and the heavy foot accent. Only lexicalised stresses (i.e. foot accents) are relevant for phonology, while the rhythmic stress is a phonetic phenomenon.

\subsection{Morae in the formalisations of phonetic results}

Estonian phoneticians understand the mora as a "minimal abstract unit of temporal regulation" (Eek and Meister 1997: 87) or as an "abstract isochronous unit of timing" (Lehiste 1990: 290). Eek and Meister $(1997,2004)$ preserved the maximal bimoraicity of the syllable and so had to use the procedure of mora-splitting/sharing with all its shortcomings: crossing association lines, generation of unattested structures, the need to treat long vowels as sequences of two identical phonemes, etc. (see Section 2.3 and Hint 2001: 170, Ehala 2003: 57, Prillop 2013: 9-10). Plüschke $(2011,2013)$ used morae just to visualise her hypothesis that in each quantity degree the pitch peak falls after the first mora, which was actually not fully confirmed by her results. She adopted trimoraic syllables and a varying duration of mora in each quantity degree, while not entering into theoretical discussions about the term itself.

A more explicitly theoretical stance on the mora is found in earlier accounts by Wiik $(1982,1985,1991)$ and Lehiste $(1960,1990,1997 a, b)$. Wiik applied morae to formalise the phonetic foot isochrony rules. He counted morae in syllables rather than segments and left aside the question of overlength. This resulted is a very simple analysis: short syllables are monomoraic, long ones bimoraic. The first short vowel of a syllable counts as one mora and all kinds of following "tails" as the second mora (Wiik 1991: 298). The foot isochrony tendency requires the second vowel of a disyllabic foot nucleus to lengthen after a monomoraic syllable and shorten after a bimoraic one (see further in Section 4).

Lehiste (1960: 51) originally treated mora as "the phonemic unit of segmental quantity" and assigned one to three morae to each segment. This resulted in syllables containing up to six morae (in type 3e 'poorti, Table 2) or with the same number of morae but belonging to two different quantities, and also cases where a Q2 syllable contained more morae than a Q3 syllable (Lehiste 1997b: 13). Lehiste admitted that the mora is a relative perceptual unit of duration, but still searched for its physical 
correlate in the "peaks of energy" inside sounds (1960: 51; weight is aligned with energy also in Gordon 2004). Lehiste (1990, 1997a) also explored mora-counting in whole syllables. Apart from the problem of moraic ambiguity of unstressed syllables, her results showed that, unlike in Japanese, "neither the syllable, nor the mora constitute the basic unit of timing" in Estonian (Lehiste 1990: 290). Her general conclusion is relatively drastic:

If it is considered desirable that phonological constructs have phonetic backing, the theories that use mora-counting as supportive evidence need to be revised; alternatively, the term "mora" should be redefined in terms other than duration (ibid.).

Lehiste rejected morae due to the theoretical unacceptability of either mora-sharing or the varying physical length of the mora. Even her disregard for the maximal bimoraicity of the syllable was not able to solve all the descriptive problems which arise with an attempt to explain all Estonian durational phenomena through morae.

\subsection{Earlier formal moraic accounts of Estonian}

There exist several formal phonological moraic accounts of Estonian both within generative (Prince 1980, Kager 1995, Hayes 1989, 1995, Bye 1997, Odden 1997, Ehala 1999, 2003) and functional (Hint 1978, 1980, 2001) frameworks. The latest generative advances by Prillop are considered in Section 3.4.

Hayes (1989) understood the mora in a dual way, as a unit of both segmental quantity and positional syllable weight, and accepted trimoraic syllables for Estonian. Prince (1980), who treated the moraic contrast as binary, recognised the non-linear nature of Estonian quantity. He saw it as "the product of multiplying a segmento-syllabic distinction (heavy/light) by a prosodic distinction (foot/nonfoot)" (ibid.: 559) and suggested that a Q3 syllable always constituted a foot on its own. This view was followed by Kager (1995), but also extensively criticised (Viitso 1982, Bye 1997, Odden 1997, Hint 2001, Ehala 2003).

First, it still implies trimoraic syllables in types like (3c), see Fig. $5 \mathrm{~b}$. Second, as a consequence, the recursive foot (consisting of a smaller foot plus unparsed syllables), had to be accepted, cf. extreme cases of a double recursion in Fig. 5a, b (Prince 1980: 530, 549). The recursive foot contradicts the classic version of Prosodic Hierarchy "word $>$ foot 
> syllable > mora" (Selkirk 1980, 1984). This hierarchy is still widely accepted in generative linguistics and prohibits feet from comprising of feet (in non-generative accounts, however, its universal validity is put under doubt, cf. Schiering et al. 2010). The recursive foot implies a combination of at least two homonymic notions of the foot with different content: " $F_{\text {stress" }}$ " and " $F_{\text {quantity" }}$ (Odden 1997: 180). The stress foot includes various kinds of structural "quantity feet" at lower levels. In the present paper, the foot is understood strictly as " $F_{\text {stress }}$ " (cf. Footnote 1), and so no recursive feet are allowed.

Also, other problematic issues of Prince's conception have been discussed:

- unattested stress patterns generated by his theory, as well as some unconfirmed data on Estonian stress patterns that he used;

- inability to account for word-initial unstressed (extrametrical) syllables;

- a need to accept either a sequence of two unparsed syllables between the two 'minimal feet' (as in Fig. 5a) or a so-called 'weak layering', in which elements are directly linked to the higher levels of the prosodic hierarchy, bypassing the lower ones (see Section 3.4);

- unnatural prosodic treatment of word-final geminates, cf. Fig. 5c (Prince 1980: 532);

- inability to account for prosodic alternations in certain declinational types.

Finally, the treatment of a Q3 syllable as a separate foot does not correspond to existing perceptual data on Estonian: "accents ...can be identified only when information about $\mathrm{V}_{2}$ has also been delivered to listeners" (Eek and Meister 1997: 91).

a.

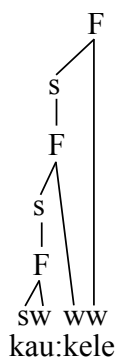

kaugele /'kaukele/

'far:ALL' b.

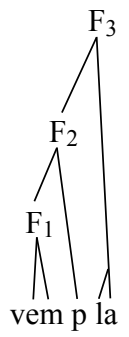

vembla /'vempla/

'cudgel.gen' c.

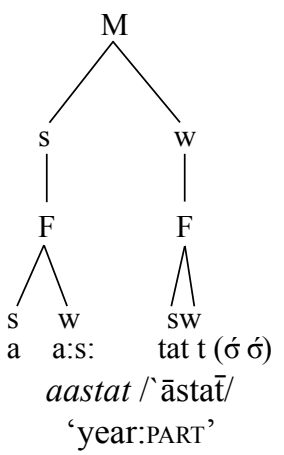

Figure 5. Some Estonian structures in Prince's interpretation 
Subsequent researchers tried to adhere to the maximal bimoraicity of the syllable even more strictly, which provoked progressive loosening of other principles of the moraic theory.

Bye (1997: 51, Fig. 6a) proposed representing Q3 syllables as formally disyllabic, with either a "degenerative" syllable or a freestanding mora. Eek and Meister (2004: 255-256), who used degenerative feet, noticed that their prosodic structure would be completely different from regular isochronic disyllabic feet. Bye accepted a ternary foot ( $k a u-u$-ge)-le in kaugele 'far:ALL' to avoid a sequence of two unparsed syllables. His framework would still imply either syllables unparsed in feet (such as -le in Fig. 6a) and trimoraic syllables in structures like (2e-f) and (3d-e) in Table 2 (Ehala 2003: 56). Even if an idea to distinguish between different prosodic levels in the phonology of quantity is fruitful in itself, the existing representational framework did not allow Prince and Bye to depict it properly.

Hint $(1978,2001)$ and Ehala $(2003)$, in turn, proposed to autosegmentalise all quantity by disconnecting it from segments and transferring it to the level of syllables. Their syllable weight distinction corresponds to the prosodic contrast of light and heavy accents in the present account. Stressed syllables with Q1 and Q2 are ascribed one mora and those with Q3 two morae, respectively. Hint (2001: 257-258) thoroughly discussed the theoretical basis of his essentially structuralist account (see Section 4.2), but did not try to express it with a formal apparatus of the moraic theory. Such an attempt was made by Ehala and turned out an impossible endeavour. Representations of Q2 and Q3 as in Fig. 6b (Ehala 2003: 58), break several important conventions of this theory, e.g. bimoraicity of long vowels and a ban on sequences of identical phonemes (Prillop 2013: 7-8). One could also wonder if a mora would be shared between four segments in structures like poorti ('border of a fabric/rug.PART' (3e)).

Ehala (2003: 77) explicitly pointed out that the syllable weight, autosegmental in nature, is treated by the moraic theory "as totally dependent on segmental structure". His representations, which also depict morae below syllables, are even more controversial than the standard moraic formalism. He is not able to reflect the autosegmental nature of morae, but is obliged by the existing representational convention to depict the link between morae and segments, actually negated by him. Besides, this convention does not allow a distinction between prosodically active (stressed) and inert (unstressed) syllables, which is a very important contrast in Hint and Ehala's framework. Ehala tried other representational alternatives, such as the dual distinction of weight by Hayes (see Section 2.2), but the latter, as said, also does not truly reflect mora autosegmentalisation. 
a.

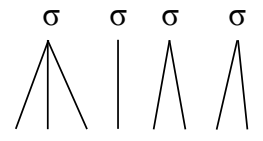

$\mathrm{k} \mathrm{a} \mathrm{u} \mathrm{u} \mathrm{k} \mathrm{e} 1 \mathrm{e}$

kaugele /'kaukele/

'far:ALL'

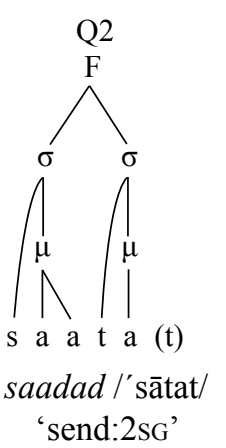

b.

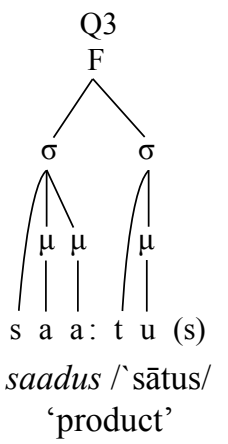

Figure 6. Some Estonian structures in (a) Bye's and (b) Ehala's interpretation

Odden (1997) gave an extremely cautious assessment of the moraic theory validity for Estonian. He analysed more than a dozen of its problematic points raised by the Estonian case, making an inquiry into the very nature of the mora and the foot. Without any resolute answers, he still concluded that a foot-based account of Estonian quantity "accords Q3 no direct status in the phonology" (Odden 1997: 190). If phonology is represented as in current moraic theory, there seem to be indeed no adequate formal tools to account for prosodic overlength.

\subsection{The latest moraic accounts of Estonian by Prillop}

Recent advances in generative Estonian phonology are represented by Prillop (2011, 2013, 2015, 2018a, 2018b) and a Government phonology account by Pöchtrager (2006, 2015). The latter uses Estonian to ground a radical proposal to give up segmental phonology altogether, not addressed here, as the mora notion is not exploited in this work.

Research by Prillop, in turn, develops the moraic theory further. This account of Estonian is even more formally sophisticated than any of the previous ones. The latest works (Prillop 2018a, b) also reveal important changes in her conception. For example, the OT framework and the distinction of strong and weak morae, heavily exploited earlier, were abandoned.

Prillop (2011: 13, 2018a: 345-348) sees the mora as a smaller building block of the syllable. However, the description of the mora's function "to distinguish between light and heavy syllables", which is 
important for the stress rules (Prillop 2018a: 349), does not match the definition perfectly. It emphasises syllable's prosodic behaviour as a whole in regards to higher level prosodic units, not its composition of smaller units.

Morae as units require exact correspondences to individual segments. Phonological quantity linearised in a single moraic tier recalls the old segmental phonological conception of Estonian quantity, extensively criticised (cf. the latest remarks in Hint 2015a, b, Pajusalu 2015). Prillop (2015: 185) explicitly admits that "in a certain sense we deal with segmental quantity degrees: $\mu-, \mu \mu$ - and $\mu \mu+$-vowels, as well as moraless, $\mu$ - and $\mu+$-consonants are contrasted". The whole four quantity degrees of vowels are identified here.

Prillop (2013: 3, 2015) sees the "consistency with regard to the phonetic facts" as one of the main advantages of her description over the previous ones. She agrees, however, that morae cannot correspond to exact milliseconds (Prillop 2011: 181-182, 2018a: 348). As discussed in Section 2.3, there is no general theory on the acceptable level of inconsistency between the two. Prillop, too, does not formulate any clear restrictions on this. Moreover, her mora has a variable duration (Prillop 2018a: 349). If no clear duration of the mora and no rules of the correspondence between duration and phonological length are set in the theory, such phonetic argumentation is not falsifiable and can be considered only as secondary in a discussion on phonological length.

Several sensitive points of her own account with regards to some relatively prominent phonetic facts can be noted regardless. Prillop $(2011,2013,2015)$ introduced so-called prominent (strong) morae (see below) and suggested that their phonetic correlate is a longer and/or more intensive pronunciation (Prillop 2015: 183). This brings us back to the peaks of energy as the mora's correlate suggested by Lehiste (see Section 3.2). However, no actual results from phonetic measurements supporting this view are cited. One could wonder how a strong mora in an unstressed syllable of Q2 (see Fig. 7a, c) and Q1 (2a ude 'fuzz', Table 2) should be realised. One might expect to find an intensity peak in the second syllable of such words. Existing research on Estonian intensity (Liiv 1985, Eek 1986, Eek and Meister 1997, Asu and Lippus 2018) has attested to no such peaks in a second syllable of Q1/Q2.

Prillop (2015: 176) also claims that pitch in Estonian always falls after the second mora. This would imply that in Q1 (cf. ude in 2a, Table 2 ) the pitch would fall inside the second syllable vowel. Ample experimental research since the 1930s has shown that pitch in Q1 falls more 
or less at the same place as in Q2, i.e. at the border between the first and the second syllable (see Lippus et al. 2009, 2013 for the latest results). Moreover, a simulated shift of the peak from the first vowel to the second in Q1 changed the native perception of primary stress patterns: 'kanata ['gana(')t'a] 'hen.ABE' was perceived as $k a$ 'natta [ga 'nat: 'a] 'also fishpot.PART' (Eek and Meister 2003: 910; transcription is mine, N.K.). Prillop (2018a: 356) already placed the pitch fall after the first mora, the same way as Plüschke (2013: 33) did.

The phonetic reduction of $\mathrm{V}_{2}$ in $\mathrm{Q} 3$ disyllables (cf. 'uude 'new.ILL' and other types in 3a-e, Table 2) was used as an argument supporting Prince's idea that a Q3 syllable exhausts the foot (Prillop 2015: 182). This $\mathrm{V}_{2}$ is claimed to be reduced exactly because it does not belong to the foot. One could wonder if the same claim should then hold for an unstressed $V_{3}$ in trisyllables. Prillop (2018a: 351) sees the foot as maximally disyllabic. Phonetic results by Lehiste (1997b: 150-151) showed that in trisyllabic Q3 words $V_{2}$ is also reduced, but not $V_{3}$. The length of $V_{3}$ is generally comparable to the length of a full short $V_{1}$, irrespective of the quantity degree of the foot. Exactly for this reason, Eek and Meister (1997: 95) phonologically treat $V_{3}$ as not belonging to their "minimal foot", while $\mathrm{V}_{2}$ is included. If both $\mathrm{V}_{2}$ and $\mathrm{V}_{3}$ do not belong to the foot, as Prillop's conception implies, vowel reduction cannot be considered as a sign of syllable's extrametricality.

An aspiration for defining the relatively fine phonetic details of each sound in a phonological representation already makes the task of Estonian quantity formalisation challenging enough. The restrictions of the moraic theory which Prillop chose to follow made it even more complicated. She adopts Prince's old idea that a Q3 syllable always makes a foot on its own (see Section 3.3) and adheres to the following main principles (Prillop 2018a: 351):

(1) the syllable is maximally bimoraic

(2) the foot is minimally bimoraic and maximally disyllabic;

(3) short vowels are monomoraic, long vowels bimoraic;

(4) short consonants are without mora, long consonants monomoraic;

(5) dependency lines in the prosodic tree do not cross.

In order to maintain these five principles, two admissions had to be made:

(6) morae can be shared/split between several sounds;

(7) weak layering (projecting elements and even their parts directly to higher levels of the hierarchy, bypassing the lower levels) is allowed. 
Weak layering, which helps to avoid the recursive foot (see Section 3.3) actually also violates the classic Prosodic Hierarchy, because the latter prohibits skipping levels. Currently there are no strict criteria in the theory about the acceptability of different variants of weak layering. This allows various ad hoc solutions: extrasyllabic consonants, unparsed syllables, and morae which are "unaffiliated with syllables and linked to higher-level prosodic constituents. It is, however, unclear which constituents can remain without a link to next level constituents and how many levels can be skipped in this way" (Prillop 2013: 11). For example, Kager and Martínez-Paricio (2018: 182) seem to allow even whole syllables unaffiliated with any higher level constituents. Prillop (2018a: 351) did not allow bypassing of more than two levels, and later added an additional restriction that levels can be skipped only at units' boundaries. However, the reasons for these particular choices and their subsequent changes were not explicitly addressed.

Strong and weak (prominent and non-prominent) morae also require a comment. This contrast was taken over from Kager (1992). The latter used Hayes' term "moraic trochee" to describe quantity sensitive stress systems where the stress falls on either all heavy syllables or on alternating light syllables. Kager, however, treats Estonian as having syllabic rather than moraic trochee (ibid.: 304), and his theory does not allow strong morae to occur outside the stressed syllables anyway. Prillop, in turn, claimed that Estonian combines two different types of rhythm: a trochaic one on the syllabic level and an iambic one on the moraic level. Moreover, the two do not necessarily coincide, as strong morae can occur in unstressed syllables (cf. Fig. 7a, c). This account is incompatible with the metrical grid theory, as it generates uncontinuous columns (Prillop 2013: 18), and actually constitutes a new amendment to a general moraic theory.

The introduction of strong and weak morae also means that one more informational layer is included in the moraic tier. In addition to quantity, now also a part of the data on prominence (which was previously calculated from the metrical grid nodes) is linearised in morae. Prillop (2013: $18,21)$, therefore, had to claim that mora strength is a lexical property, even if it cannot create lexical length contrasts. No wonder that an extremely sophisticated machinery was needed when so much information had to be included in morae. Notably, strong and weak morae do not appear anymore in Prillop (2018a, b), for unclarified reasons.

As an example, let us examine how Q2-Q3 disyllabic feet with the most complex first syllable structures (VVCC and VVCCC) 
are analysed. The most optimal (in an OT sense) representations for 'uute - 'uute (types $2 \mathrm{e}-3 \mathrm{~d}$ in Table 2, Fig. 7a-b) follow Prillop (2013: 23, 2015: 184), while in Prillop (2018a: 355) the mora strength is no longer depicted. Earlier variants of 'kaarte - 'kaarte (types $2 \mathrm{f}-3 \mathrm{e}$ in Table 2) structural types are represented in Fig. 7c-d (Prillop 2015: 24). In Prillop (2018a: 360), a prosodic tree for the 'VVCCC type underwent some significant modifications, which are represented in Fig. 7e (the same type as in Fig. 7c).

a.

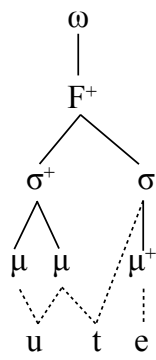

uute /'ū $\overline{\mathrm{u}} \mathrm{e} /$ b.

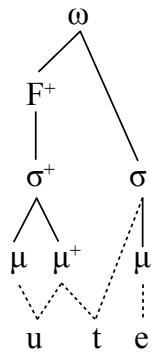

uute / ' $\overline{\mathrm{u}} \overline{\mathrm{te}} /$ c.

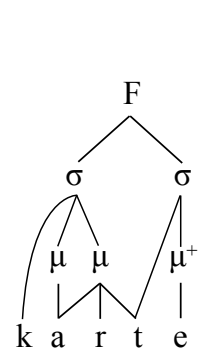

kaarte /'kārte/ kaarte /'kārte/

'arc'GEN.PL' 'map PART DL'

d.

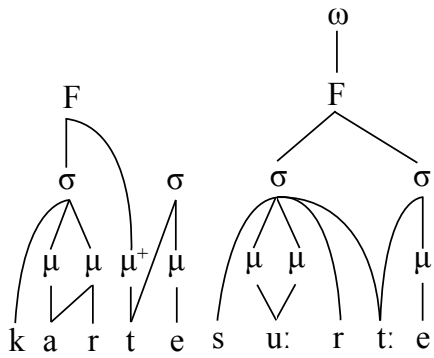

suurte/'sūrte/

'big:GEN.PL'

Figure 7. Complex Estonian structures in Prillop's earlier (a-d) and later (e) interpretation

Maximal bimoraicity of the syllable and the long vowels are preserved, but at a high cost. Several problematic points for a classical moraic theory and even Prillop's own basic postulates are listed below.

(1) As said, the recursive foot is avoided due to the acceptance of weak layering, which accepts direct projections both from segments to syllables and from morae to feet (cf. Fig. 7c-d). Projections of one segment's parts to two different levels (moraic and syllabic, see geminate $t$ in Fig. 7a-d) are also permitted, while no restrictions on this are formulated.

(2) The mora can be shared across syllabic and even foot boundaries (Fig. 7b). In the earlier version, it could also split between three segments (Fig. 7c). In the later version, this issue is resolved by projecting both parts of the geminate directly to a syllabic level (Fig. 7e). However, such a representation violates one of the basic principles outlined above: a long (fortis) consonant should have one mora (in Fig. 7e, it has none). Notably in a monosyllabic form 'suurt 'big:PART' the final fortis 
consonant has a mora (Prillop 2018a: 360). Unfortunately, clear criteria to distinguish between the cases of fortis consonants with and without a mora were missing.

(3) Not all syllables are parsed into feet and not even all morae are parsed into syllables (cf. with Bye's freestanding morae in Section 3.3).

(4) While long vowels are always treated as bimoraic, first syllable diphthongs are treated as either monomoraic (sharing a mora) or bimoraic, depending on the quantity degree (Prillop 2015: 177). However, initial syllable diphthongs and long vowels manifest the same prosodic behavior, so it remains unclear why the two should be represented differently. Besides, Estonian diphthongs are combinations of two phonemes rather than single phonemes (Viitso 2003: 2). Mora sharing in a Q2 diphthong therefore violates one of Prillop's main postulates that a short vowel should always have one mora.

(5) As discussed before, an amendment on the combination of syllabic and moraic trochees in the same language, especially when strong morae can occur outside of strong (stressed) syllables, would be very difficult to incorporate into a standard moraic theory.

\subsection{Validity of Prillop's analysis for Soikkola Ingrian}

Prillop (2015) applied her moraic analysis also to the Soikkola dialect of Ingrian. She uses this Finnic variety with a ternary quantity contrast of consonants, similar to Estonian, as a support for the existence of strong and weak morae. A brief comment on her analysis will be made.

One of its sensitive points is an incomplete dataset: proposed generalisations do not embrace the entire language system. For example, a rule that stops and $s$ were geminated if the next syllable contained a diphthong or long vowel (Prillop 2015: 189) is not a general one. In trisyllabic feet, those consonants could be geminated also before short vowels, which created four-way contrastive patterns ( $4 a-d$ in Table 3 , Kuznecova 2015: 207-208).

Prillop (2015: 190) claimed that Soikkola Ingrian "tends to preserve original durational contrasts of words, syllables and segments". However, strong reduction characteristic of at least the modern state of the dialect leads to typological changes in the durational contrast of non-initial vowels. An original short vs. long vowel contrast turns into a reduced vs. short vowel contrast (Kuznecova 2009, Markus 2011, Kuznetsova 2016). 
According to our recent phonetic research (Kuznetsova and Brodskaya, in prep.), the original contrast of non-initial long and short vowels is nowadays lost from trisyllabic feet. Phonetically long second syllable vowels occur only in structures with the shortest foot nuclei (types $4 \mathrm{e}-\mathrm{f}$ in Table 3), while lost from longer structural types (e.g. 4b, d in Table 3). Therefore, the statement that "original non-initial long vowels are linked to strong morae and short vowels to weak morae" (Prillop 2015: 190) does not hold in both of its parts. On the contrary, the only vowels which are nowadays phonetically long in the second syllable of trisyllables are exactly those which were short in Proto-Finnic (types 4e-f in Table 3), while all original long vowels in this position shortened.

Table 3. Changes in trisyllabic feet of Soikkola Ingrian

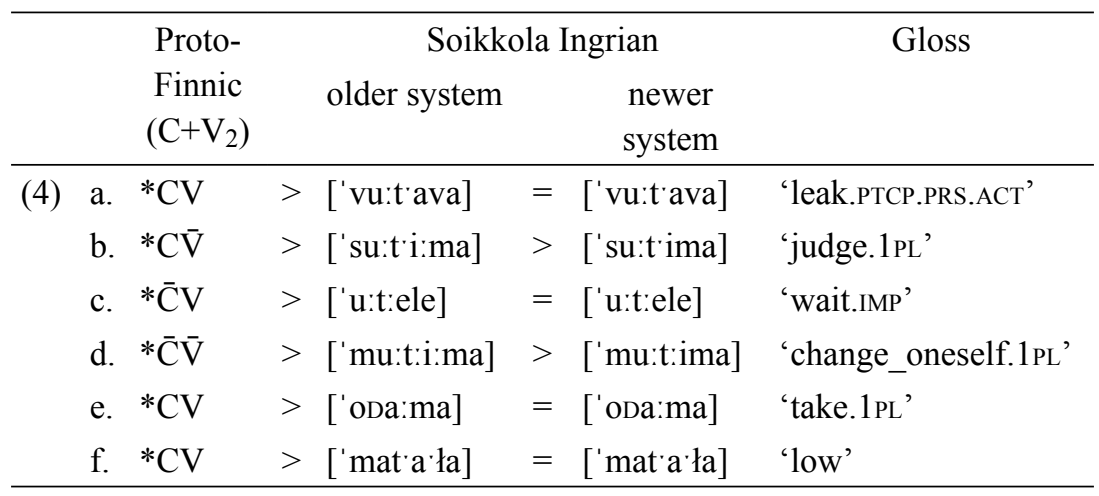

\section{Estonian syllable weight in the structural functional perspective}

\subsection{Morae in the structure of Estonian quantity}

Functional structuralism treats the language as a set of hierarchically organised and mutually associated layers of information, each of which has its own function in enabling effective communication. In fact, there are several hierarchies which are associated to each other (cf. "double articulation" in Martinet 1949/1965, also Fox 2000: 333-344). Length, among other linguistic phenomena, is also "a property of units of different levels" (Fox 2000: 110). Physical duration of sounds in concrete utterances is influenced by multiple phonological and phonetic factors, each of which belongs to a concrete level of a certain hierarchy. Additionally, various pragmatic and even metalinguistic components, 
such as age, gender, social status, mood, health of a speaker, can affect these concrete durations.

Let us analyse structural composition of Estonian quantity up to the level of the foot. Postlexical phenomena are outside the scope of this paper and involving the prosodic word level would require an additional discussion on a non-trivial question of primary and secondary stress in Estonian (viz. Kuznetsova 2018). Our main questions will be the structure of Estonian foot accents and the place of morae in it.

Kasevič et al. (1990: 20) typologically described any word-prosodic unit through its association to three basic structural units: (1) a domain (segmental unit associated with it); (2) a bearer (minimal segmental structure which has to be present to make its realisation possible); (3) a functional basis (morphological unit associated with it). Estonian accents have the foot as their domain, the foot nucleus as a bearer, and the morpheme as a functional basis. Two relevant prosodic levels are distinguished in Table 4: the syllable and the foot. They both are associated with the morphemic level in a parallel grammatical hierarchy. Besides, both hierarchies are associated with the segmental level, which is subprosodic and subgrammatical. Quantitative phenomena are divided into two types: phonological and phonetic. The latter are outlined tentatively and can include, for example, intrinsic duration of segments of different quality on the segmental level. On the prosodic levels, phonetic information on quantity would define, for example, the exact distribution of durational peaks and reduction among segments and syllables in various types of feet.

Table 4. Structure of Estonian quantity up to the foot level

\begin{tabular}{|c|c|c|c|c|}
\hline \multirow{2}{*}{$\begin{array}{c}\text { (Levels of } \\
\text { grammatical } \\
\text { units) }\end{array}$} & \multirow{2}{*}{$\begin{array}{l}\text { Level of } \\
\text { prosodic } \\
\text { units }\end{array}$} & \multirow[t]{2}{*}{$\mathrm{Nr}$} & \multicolumn{2}{|c|}{ Main quantitative phenomena } \\
\hline & & & $\begin{array}{l}\text { Phonology } \\
\text { (a) }\end{array}$ & $\begin{array}{l}\text { Phonetics } \\
\text { (b) }\end{array}$ \\
\hline \multirow[t]{2}{*}{ (Morpheme) } & Foot & 3 & $\begin{array}{l}\text { light vs. } \\
\text { heavy accent } \\
\text { (=lexicalised } \\
\text { foot stress) }\end{array}$ & $\begin{array}{l}\text { e.g. phonetic rules for a } \\
\text { distribution of lengthening } \\
\text { and shortening between } \\
\text { syllables in a foot (incl. foot } \\
\text { isochrony tendency) }\end{array}$ \\
\hline & Syllable & 2 & $\begin{array}{l}\text { long vs. short } \\
\text { syllables } \\
\text { (mono- vs. } \\
\text { bimoraic) }\end{array}$ & $\begin{array}{l}\text { e.g. phonetic rules for a } \\
\text { distribution of lengthening } \\
\text { and shortening between } \\
\text { segments in a syllable }\end{array}$ \\
\hline Segment & & 1 & $\begin{array}{l}\text { long vs. short } \\
\text { phonemes }\end{array}$ & $\begin{array}{l}\text { e.g. intrinsic duration of } \\
\text { segments }\end{array}$ \\
\hline
\end{tabular}


Morae in the generative accounts of Estonian discussed above can represent in total five different quantity components simultaneously: 1-3(a) and 2-3(b), marked bold in Table 4. In order to represent all the desired contrasts without violating some basic theoretical principles, progressively more sophisticated analytical mechanisms have been invented. Yet, no account has yet managed to preserve internal theoretical consistency entirely.

In a functional structural framework, morae are reserved just for a component $2 \mathrm{a}$, which is put in a bold frame in Table 4. Morae are considered not as syllable constituents, but as an analytical measure of the syllable's prosodic properties (cf. Section 2.1). The main prosodically relevant syllabic contrast in Estonian, as outlined in Section 3.1, is of short and long syllables (or mono- vs. bimoraic, or light vs. heavy syllables). It serves as the basis for the accent distinction at a higher foot level. Feet with a stressed long syllable can carry two types of accent, while feet with a stressed short syllable carry only one. Accents are distinctive word-prosodic units, such as tones, and should rather be represented autosegmentally.

Estonian morae characterise the weight just of syllables, not of feet, and therefore do not account for overlength. The Estonian syllable weight contrast is, in a sense, auxiliary and can be automatically detected from the segmental composition of syllables. Only the contrasts of segmental quantity and of accents need to be depicted in the phonological transcription.

\subsection{Structural moraic analysis by Hint}

The moraic account of Estonian by Hint (1978, 2001: 257-258) is also essentially structuralist, and naturally arrived at a complete autosegmentalisation of morae from segments. A brief comment on its differences from the present conception will be given.

Long vowels and consonants are considered as iterations of two short segments. The question on mono- vs. biphonemic character of Estonian long sounds has been extensively discussed in literature (see e.g. Viitso 2008: 184-189), and no final consensus has been yet reached. Long sounds do not contain any internal phonetic boundaries, and for a number of functional reasons they are treated here as monophonemic (as in Erelt et al. 1995: 102-103).

Hint makes a distinction between phonetic and phonological rules for quantity, similar to the one proposed in Section 4.1. He states that a phonetic description of the syllable structure should determine the 
way Q3 is realised inside the syllable, while its phonological description should determine the quantitative peak placement. However, as explicated in Table 4, an exact description of peak placement in a syllable and foot also belongs to the phonetic description. The place of peak can be automatically detected if one knows the syllable and foot structures and the foot accent type. Therefore, it is enough for a phonological transcription just to mark the syllable serving as a morphological anchor of accents.

Most importantly, overlength is regarded as a syllabic feature by Hint. That is why he used morae to describe the contrast between the presence and absence of overlength in stressed syllables: "the weight of one mora is obtained from the segmental composition of the syllable, and of the second mora from the prosodic syllabic extra-quantity (heavy accent, heavy stress, extra stress)" (Hint 2001: 257-258). He saw stress and overlength as two separate prosodic phonemes added to segmental syllabic structures. Syllabic extra-quantity can occur only in long stressed syllables, while Q1 and Q2 syllables have stress only as a prosodic marker. Therefore, the latter, as well as all unstressed syllables are monomoraic.

Hint's wording does not allow lexicalised and rhythmic stresses to be distinguished in the case of Q1 and Q2. Only lexicalised stress (light accent) will be a "prosodic phoneme" to be depicted in a phonological description. Rhythmic stress, which has the same phonetic cues as the light accent, is a phonetic phenomenon.

In the present paper, overlength is seen as a property of lexicalised stress, i.e. the accent (like in Viitso 1979, 2008 and Eek 1986), rather than a separate feature. The accent has the foot as its domain and the disyllabic foot nucleus as its bearer (therefore, no accentual contrast in monosyllabic feet is present), even if it is morphologically anchored in a certain syllable of a morpheme. The morae, as syllabic features, do not, therefore, constitute an appropriate tool for formalising overlength.

\subsection{Functional evidence for the prosodic contrast of short and long syllables}

Let us now examine further phonological and phonetic evidence that only the contrast of long and short syllables is indeed functionally relevant at the syllabic level.

Phonologists have long discussed whether Estonian is a mora- or a syllable-counting language. Already Ojamaa (1976: 45) noticed that Estonian could be considered mora-counting on the basis of a Q1 vs. 
Q2 distinction, and syllable-counting on the basis of a Q3 vs. non-Q3 distinction. Hint (1978) analysed the dynamics of changes in Estonian nominal declension and concluded that Estonian is turning from a moracounting into a syllable-counting language. "The distinction between inflectional classes that was formerly based on the quantity of the first syllable is on the way out" (Lehiste 1983: 26).

Viitso (1982), however, re-analysed Hint's data and offered a simpler and more general algorithm which calculates the rules for the choice of affixes both at an earlier and at a later stage of Estonian morphonological development. This algorithm is based on the contrasts of short vs. long stressed syllables and of two accents in a long syllable. The morphonological change is explained by the loss of a light accent in certain syllables. Tendencies for the secondary stress loss from noninitial syllables and the primary stress shift to initial syllables are general widespread processes in Estonian (Viitso 1979, 1982, 2003, Pajusalu 2009). They signify a drift towards a replacement of marked stress patterns by unmarked ones. Viitso concluded that mora-counting is not needed to explain the processes described by Hint and that Estonian was stress-counting already at the initial stage of those processes. Hyman (1985: 93), Kager (1992), and Alber (1997) also assumed that overlength is not counted in the rules of stress placement.

Studies on runic poetry (Ross and Lehiste 2001: 57-58) showed that Estonian folklore metre indeed does not distinguish between long and overlong syllables. A contrast of long and short lexically stressed syllables is, in turn, of utmost importance. Long stressed syllables have to fall in an ictus position, while short stressed syllables have to avoid it (in the latter case, the second syllable half-long vowel gets the ictus). In modern poetry and modern readings of traditional poetry, this system is being replaced with a trivial correspondence between ictuses and stressed syllables, so the syllable weight sensitivity is being lost (Ross and Lehiste 2001, Lehiste 1990, 1997a). Still, it is exactly the contrast of short and long stressed syllables that is indicated in the old system as being prosodically relevant.

A prosodic phonetic tendency to foot isochrony provides further proof of this. Wiik (1991) formulated an elegant rule: a short vowel of the second syllable is phonetically lengthened after a monomoraic (short) syllable and shortened after a bimoraic (long) one (see 3.2). In the history of Estonian and many other Finnic varieties, both reduction and apocope after a long syllable and phonetic lengthening after a short syllable are extremely typical processes attested to various degrees (viz. Kuznetsova 2016). For example, in Soikkola Ingrian, this lengthened short vowel after 
a monomoraic syllable is phonetically much longer than the original long vowel after a bimoraic syllable (see the research cited in Section 3.5).

\subsection{Possible formalisations of the functional-structural account of Estonian quantity}

If a generative moraic theory cannot provide adequate tools for the representation of Estonian quantity within a functional-structural framework, other possibilities could be explored. For example, we can try to model a morphonological process of a synthesis of Estonian accents (cf. 'suurte in Fig. 8). Both phonological and morphonological information is needed to calculate the accent, so two parallel processes will be considered. In phonology, first, the phonemic length of segmental phonemes has to be detected (this corresponds to the CV-tier in early versions of moraic theory). On the next step, a quantitative structure of syllables is determined. Next, the syllabic structure tells us the syllable weight, which will play a role in higher-level prosodic processes. Finally, on the foot level, we learn about the structure and the boundaries of the whole foot and the place of the foot stress.

In morphophonology, first, the segmental structure of each allomorph is established. Then we obtain information about the type of allomorph. Main types of morphemes in Estonian are roots, derivative suffixes and segmental and suprasegmental inflectional morphemes (cf. Viks 1992, Erelt et al. 1995). Roots can have at maximum three prosodic types of allomorphs. First, it is a monosyllabic stem (Rmon) with a heavy accent. Second, it is a multisyllabic "vocalic" stem which carries light accent by default for most words ( $\mathrm{R}$, or its abridged variant $\mathrm{R}-$ ), apart from the class of so-called contracted roots. The latter have the default vocalic stem with a heavy accent (Rs) and also an additional lightly-accented stem (Rw). The default stem for most nouns can be obtained from a genitive singular form, $\mathrm{Rw}$ from a partitive singular form. Next, we establish the prosodic properties of morphemes in regards to the accent. Following the principle outlined for Proto-Slavonic by Zalizn'ak (1985), Estonian morphemes could be classified into those attracting and non-attracting accent ( $m+$ and $m$ in Fig. 8). Accent-attracting morphemes (e.g. all roots, apart for certain unaccented personal pronouns) require an accent either on their first syllable or on the last syllable of a preceding morpheme (like all suprasegmental morphemes and a derivative suffix -nna meaning female actors). The phonological domain of the accent is the foot, and its morphological domain is an accent-attracting morpheme, optionally 
followed by unaccented morphemes. Finally, the type of accent is defined for each morphological domain.

In the end, phonological and morphological information is synthesised to obtain accents in an actual grammatical word. The word suurte contains one disyllabic foot with the first heavy syllable, on the one hand, and a sequence of an accent-attracting and unaccented morphemes, which would require a default accent for a vocalic stem, i.e. light.

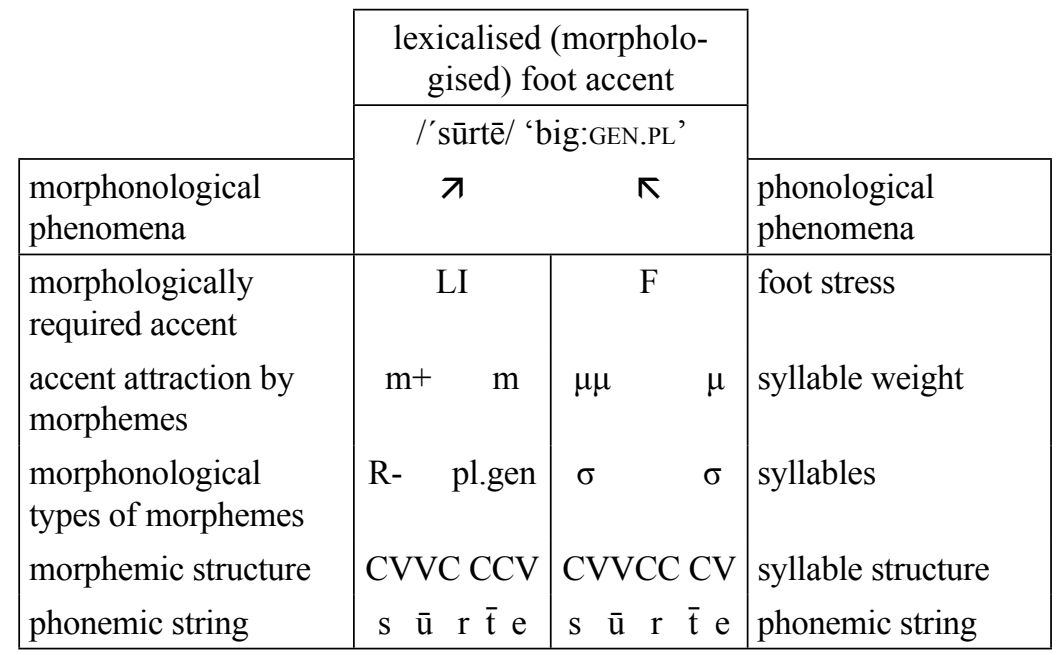

Figure 8. Example of calculating a foot accent in 'suurte

Further examples illustrate some other important phenomena in the accent synthesis. A structural difference between the light accent and the rhythmic stress is illustrated in two multifoot words given in Fig. 9: a compound with two accent-attracting morphemes (Fig. 9a) and a simplex word with one accent-attracting morpheme (Fig. 9b). The latter will have two foot stresses, but only one lexicalised accent.

a.

\begin{tabular}{|c|c|c|c|c|}
\hline \multicolumn{3}{|c|}{ /'kana'muna/ 'egg' ('hen+egg') } & \multicolumn{2}{|c|}{ /'kavalama/ 'cunning:CPR.GEN' } \\
\hline LI & $\mathrm{F}$ & $\mathrm{F}$ & LI & $\mathrm{F}$ \\
\hline $\mathrm{m}+$ & $\mu$ & $\mu$ & $\mathrm{m} \cdot \mathrm{m}$ & $\mu \quad \mu \quad \mu$ \\
\hline $\mathrm{R}$ & $\sigma$ & $\sigma$ & cmp.gen & $\begin{array}{ccc}\sigma & \sigma & \sigma\end{array}$ \\
\hline $\mathrm{CVCV} \mathrm{CVCV}$ & $\mathrm{CV} \mathrm{C}$ & $\mathrm{CV} \mathrm{CV}$ & $\mathrm{CVCVCV} \mathrm{CV}$ & $\mathrm{CV} \mathrm{CV} \mathrm{CV} \mathrm{CV}$ \\
\hline $\mathrm{kanamuna}$ & $\mathrm{ka} \mathrm{n}$ & $\mathrm{muna}$ & $\mathrm{kavalama}$ & $\mathrm{ka} v \mathrm{a} 1 \mathrm{ama}$ \\
\hline
\end{tabular}

Figure 9. Calculating foot accents in a complex vs. simplex multifoot word 
Fig. 10a shows a suprasegmental morpheme of partitive, which changes the accent of the whole foot into heavy. An example of a word containing the contracted stem (Rs) and also a derivative suffix '-line with prosodic properties similar to nouns (such morphemes are marked as $\mathrm{ADJ}, \mathrm{ADJ}-$, ADJmon) is given in Fig. 10b.

a.

b.

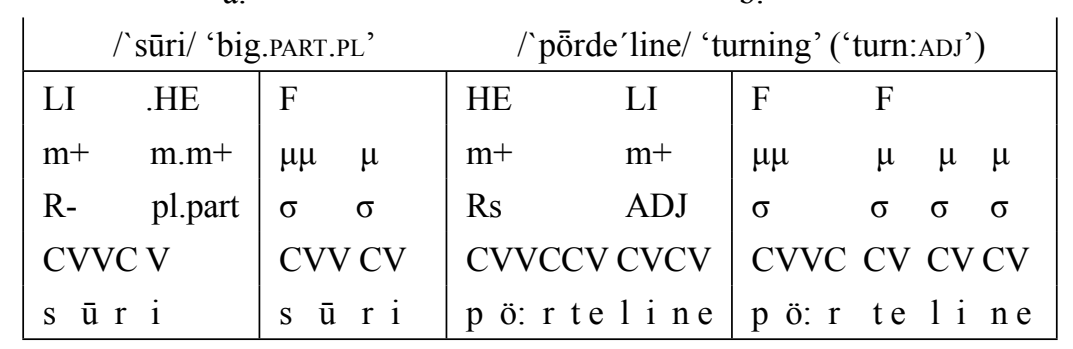

Figure 10. Calculating foot accents in 'suuri and 'pöörde'line

Some prosodic differences between adjective suffixes which are prosodically close to nouns (ADJ) and proper nominal stems (R) could be observed in pairs like those in Fig. 11 (cf. Viitso 1979: 144, 2008: 182). A trisyllabic word can be composed of two feet, but this is a marked stress model and there is a tendency to lose the stress of a final monosyllabic foot. This, however, does not seem to happen if such a foot contains a root morpheme (10a), while it is more common in adjective derivative suffixes (10b). As a result, derivatives like kasulik 'useful' in Fig. 11b face a prosodic conflict between phonology and morphonology. On the one hand, the foot structure can manifest a lack of the second foot stress. On the other hand, the system of prosodic morphonological alternations imposes heavy accent on the last syllable. Eventually, to resolve this conflict such words start changing their declension type, as described by Hint (1978) and Viitso (1982). A functional-structural description of accents, which takes into account both phonological and morphonological information, can predict such changes in the system, as it clearly traces this prosodic conflict. 
a.

b.

\begin{tabular}{|c|c|c|c|c|c|c|c|}
\hline \multicolumn{3}{|c|}{ /'tuli'tik/ / 'match' ('fire+stick') } & \multicolumn{5}{|c|}{ /'kasu(')lik/ / 'useful' ('use:ADJ') } \\
\hline $\mathrm{HE}$ & $\mathrm{F}$ & $\mathrm{F}$ & LI & $\mathrm{HE}$ & $\mathrm{F}$ & & (F) \\
\hline $\mathrm{m}+$ & $\mu \quad \mu$ & $\mu \mu$ & $\mathrm{m}-$ & $\mathrm{m}+$ & & $\mu$ & $\mu \mu$ \\
\hline Rmon & $\sigma \quad \sigma$ & $\sigma$ & & ADJmon & & $\sigma$ & $\sigma$ \\
\hline CVCV CVCC & $\mathrm{CV} \mathrm{C}$ & $\mathrm{CVCC}$ & $\mathrm{Cl}$ & $\mathrm{CVCC}$ & & $\mathrm{CV}$ & $\mathrm{CVCC}$ \\
\hline $\mathrm{t} u \mathrm{li} \mathrm{t} \mathrm{i} \overline{\mathrm{k}}$ & $\mathrm{t} u l i$ & $\mathrm{t} \mathrm{i} \overline{\mathrm{k}}$ & & $1 \mathrm{i} \overline{\mathrm{k}}$ & $\mathrm{k} \mathrm{a}$ & $\mathrm{su}$ & $1 \mathrm{i} \overline{\mathrm{k}}$ \\
\hline
\end{tabular}

Figure 11. Calculating foot accents in compounds vs. derivatives

\section{Conclusion}

To sum up, the mora notion might be of use in a structural functional description of Estonian phonology to formalise the prosodic distinction of short (light) and long (heavy) syllables, which can be used, for example, in larger cross-linguistic comparisons on syllable weight. The relevance of this prosodic distinction of syllables can be traced in actual functioning of Estonian prosody. Other quantity contrasts, relevant for Estonian phonology, belong either to the segmental, or to the foot level.

The mora is understood in the structural phonology as an abstract property rather than a constituent of the syllable. Therefore, the formal apparatus of current generative moraic theory, which places morae inside a dependency grid, is not suitable for a structuralist description. At present, the moraic theory has not yet found a way to describe such a complex multilevel quantity system as Estonian without serious internal contradictions or ad hoc theoretical solutions. As argued, this is a consequence of linearising a hierarchically organised quantity system into a single prosodic tier of morae, with just a binary contrast of mono- vs. bimoraic syllables.

Autosegmental representation of morae, showing associations between the levels of different hierarchies rather than dependencies, reflects a structural functional conception of Estonian quantity much better. Possible use of morae in the structural formalism was demonstrated in a morphonological algorithm calculating Estonian accent placement. 


\title{
Acknowledgements
}

I am grateful to Pavel Iosad, Cormac Anderson, Larry Hyman, Brittany Blankinship, an anonymous reviewer, and the editors of the present volume for their valuable comments.

\author{
Address \\ Natalia Kuznetsova \\ Institute for Linguistic Studies \\ Russian Academy of Sciences \\ Tuchkov per. 9 \\ 199053, St. Petersburg, Russia \\ E-mail: nkuzn@yandex.ru
}

\section{References}

Alber, Birgit (1997) "Quantity sensitivity as the result of constraint interaction". In Geert Booij, Jeroen van de Weijer, eds. Phonology in progress - progress in phonology, 1-45. (HIL Phonology Papers, 3.) The Hague: Holland Academic Press.

Allen, W. Sidney (1965) Vox Latina. Cambridge: Cambridge University Press.

Asu, Eva Liina and Pärtel Lippus (2018) “Acoustic correlates of secondary stress in Estonian”. In Katarzyna Klessa, Jolanta Bachan, Agnieszka Wagner, Maciej Karpiński, and Daniel Śledziński, eds. 9th International Conference on Speech Prosody 2018, 13-16 June 2018, Poznań, Poland, 602-606. Poznań: Adam Mickiewicz University.

Asu, Eva Liina, Pärtel Lippus, Karl Pajusalu, and Pire Teras (2016) Eesti keele hääldus. (Eesti keele varamu, 2.) Tartu: Tartu Ülikooli Kirjastus.

Broselow, Ellen, Su-I Chen, and Marie Huffman (1997) "Syllable weight: convergence of phonology and phonetics". Phonology 14, 47-82.

Bye, Patrik (1997) “A generative perspective on 'overlength' in Estonian and Saami”. In Estonian prosody, 36-68. Tallinn.

Eek, Arvo (1986) "Problems of Estonian word prosody". Estonian Papers in Phonetics 1984-1985, 14-66.

Eek, Arvo (1990) "Units of temporal organisation and word accents in Estonian”. Linguistica Uralica 26, 4, 251-263.

Eek, Arvo and Einar Meister (1997) "Simple perception experiments on Estonian word prosody: foot structure vs. segmental quantity". In Estonian prosody, 71-99. Tallinn.

Eek, Arvo, and Einar Meister (2003) "Foneetilisi katseid ja arutlusi kvantiteedi alalt (I): Häälikukestusi muutvad kontekstid ja välde”. Keel ja Kirjandus 46, 11, 815-837; 12, 904-918. 
Eek, Arvo and Einar Meister (2004) "Foneetilisi katseid ja arutlusi kvantiteedi alalt (II). Takt, silp ja välde". Keel ja Kirjandus 47, 4, 251-271; 5, 337-357.

Ehala, Martin (1999) "Eesti väldete probleemi üks lahendusi”. Keel ja Kirjandus 6, $378-385 ; 7,453-465$.

Ehala, Martin (2003) "Estonian quantity: implications for Moraic Theory". In Diane Nelson and Satu Manninen, eds. Generative approaches to Finnic and Saami linguistics, 51-80. Stanford: CSLI Publications.

Erelt, Mati, Reet Kasik, Helle Metslang, Henno Rajandi, Kristiina Ross, Henn Saari, Kaja Tael, and Silvi Vare (1995) Eesti keele grammatika I. Morfoloogia. Sõnamoodustus. Tallinn: Eesti Keele Instituut.

Erwin, Sean (1996) "Quantity and moras: amicable separation". In Matthew Pearson and Ileana Paul, eds. The structure of Malagasy. Vol. 1, 2-30. (UCLA Occasional Papers in Linguistics, 17.) Los Angeles: University of California, Los Angeles.

Estonian prosody = Lehiste, Ilse, and Jaan Ross, eds. (1997) Estonian prosody: papers from a symposium. Tallinn: Institute of Estonian Language.

Fox, Anthony (2000) Prosodic features and prosodic structure: The phonology of 'suprasegmentals'. Oxford: Oxford University Press.

Goldsmith, John A. (1976) Autosegmental phonology. Unpublished Doctoral Thesis. Swarthmore College.

Gordon, Matthew (2004) “Syllable weight”. In Bruce Hayes, Robert Kirchner and Donka Steriade, eds. Phonetically based phonology, 277-312. Cambridge: Cambridge University Press.

Hall, Kathleen C., Elizabeth Hume, T. Florian Jaeger, and Andrew Wedel (2018) “The role of predictability in shaping phonological patterns". Linguistics Vanguard, 20170027.

Hayes, Bruce (1989) "Compensatory lengthening in moraic phonology". Linguistic Inquiry 20, 2, 253-306.

Hayes, Bruce (1995) Metrical stress theory: principles and case studies. Chicago and London: The University of Chicago Press.

Hint, Mati (1973) Eesti keele sõnafonoloogia I. Rõhusüsteemifonoloogia ja morfofonoloogia põhiprobleemid. Tallinn: Eesti NSV Teaduste Akadeemia.

Hint, Mati (1978) "Changes in the prosodical system of contemporary Estonian". Estonian Papers in Phonetics 1978, 39-43.

Hint, Mati (1980) "Minevikuline ja tulevikuline aines keelesüsteemis. Prosoodiatüübi nihked ja selle tagajärjed". Keel ja Kirjandus 23, 215-223, 271-278, 349-355.

Hint, Mati (1997) “The Estonian quantity degrees in prosody and morphophonology”. In Estonian prosody, 125-135. Tallinn.

Hint, Mati (2001) "Prosoodiaväitluste läbimurdeta”. Keel ja Kirjandus 2, 164-172; 3, 252-258; 4, 324-339.

Hint, Mati (2015a) "Kolme häälikuvälte eksituste mehaanika". Keel ja Kirjandus 3, $163-177$.

Hint, Mati (2015b) "Eesti väldete uurimine ei ole veel ajaloo lõpus". Keel ja Kirjandus 4, 268-269.

Hubbard, Kathleen (1994) Duration in moraic theory. Unpublished Doctoral Thesis. University of California, Berkeley. 
Hyman, Larry (1985) The theory of phonological weight. (Publications in Language Sciences. 19.) Dordrecht, Holland and Cinnanminson, NJ: Foris.

Jakobson, Roman (1931/1962) "Die Betonung und ihre Rolle in der Wort- und Syntagmaphonologie”. In Roman Jakobson. Selected writings. Vol. 1, 117-136. The Hague: Mouton.

Jakobson, Roman (1937/1962) "Über die Beschaffenheit der prosodischen Gegensätze”. In Roman Jakobson, Selected Writings. Vol. 1, 254-261. The Hague: Mouton.

Kager, René (1992) "Shapes of the generalized trochee". In Jonathan Mead, ed. The Proceedings of the Eleventh West Coast Conference on Formal Linguistics, 298-312. Chicago: University of Chicago Press.

Kager, René (1995) “Ternary rhythm in alignment theory”. Utrecht University: Rutgers Optimality archive. Available online at $<$ http://roa.rutgers.edu/files/35-1094/35-1094KAGER-0-0.PDF $>$. Accessed on 30.01.2018.

Kager, René, and Violeta Martínez-Paricio (2018) "Mora and syllable accentuation: typology and representation". In Rob Goedemans, Jeff Heinz, and Harry van der Hulst, eds. The study of word stress and accent: theories, methods and data, 147-186. Cambridge: Cambridge University Press.

Kapatsinski, Vsevolod (2018) Changing minds changing tools: from learning theory to language acquisition to language change. Cambridge: MIT Press.

Kasevič, Vadim B. (1983) Fonologičeskie problemy obščego i vostočnogo jazykoznanija. Moskva: Nauka.

Kasevič, Vadim B., Evgenija M. Šabel'nikova, and Viktor V. Rybin (1990) Udarenie i ton v jazyke i rečevoj dejatel'nosti. Leningrad: Izd-vo LGU.

Kuryłovič, Jerzy (1948) “Contribution à la théorie de la syllabe”. Bulletin de la Société Polonaise de Linguistique 8, 80-114.

Kuznecova, Natalia V. (2009) "Suprasegmentnaja fonologija sojkinskogo dialekta ižorskogo jazyka v tipologičeskom aspekte”. Voprosy jazykoznanija 5, 18-47.

Kuznecova, Natalia V. (2015) "Dve fonologičeskie redkosti v dialektah ižorskogo jazyka”. Acta linguistica Petropolitana 11, 2, 201-257.

Kuznetsova, Natalia (2016) "Evolution of the non-initial vocalic length contrast across Finnic varieties of Ingria and the adjacent areas". Linguistica Uralica 52, 1, 1-25.

Kuznetsova, Natalia (2018) "What Danish and Estonian can tell to modern word-prosodic typology". In Rob Goedemans, Jeff Heinz, and Harry van der Hulst, eds. The study of word stress and accent: theories, methods and data, 102-143. Cambridge: Cambridge University Press.

Kuznetsova, Natalia and Irina Brodskaya (in prep.). "Temporary structure of the trisyllabic foot in Soikkola Ingrian".

Lehiste, Ilse (1960) "Segmental and syllabic quantity in Estonian". In American studies in Uralic linguistics, 21-82. (Indiana University Publications. Uralic and Altaic Series 1.) Bloomington: Indiana University Press.

Lehiste, Ilse (1983) "Prosodic change in progress: evidence from Estonian". In Irmengard Rauch and Gerald F. Carr, eds. Language change, 10-27. Bloomington: Indiana University Press. 
Lehiste, Ilse (1990) "Moraic analysis of Finnish and Estonian". In Congressus Septimus Internationalis Fenno-Ugristarum, Sessiones sectionum 3B (Section "Dissertationes: Linguistica”), 286-291. Debrecen: Kossuth Lajos Tudományegyetem.

Lehiste, Ilse (1997a) "The phonetic realization of the haiku form in Estonian poetry, compared to Japanese". In Kiritani Shigeru, Hajime Hirose, and Hiroya Fujisaki, eds. Speech Production and language: In Honor of Osamu Fujimura, 241-249. (Speech Research, 13.) Berlin: Mouton de Gruyter.

Lehiste, Ilse (1997b) “The structure of trisyllabic words”. In Estonian prosody, 149-164. Tallinn.

Liiv, Georg (1985) “Akustičeskije korrel'aty èstonskogo slovesnogo udarenija v sootnošenii s differencial'noj dolgotoj”. Sovetskoe finno-ugrovedenije 21, 1, 1-13.

Lippus, Pärtel, Eva Liina Asu, Pire Teras, and Tuuli Tuisk (2013) "Quantity-related variation of duration, pitch and vowel quality in spontaneous Estonian". Journal of Phonetics 41,1, 17-28.

Lippus, Pärtel, Karl Pajusalu, and Jüri Allik (2009) “The tonal component of Estonian quantity in native and non-native perception". Journal of Phonetics 37, 4, 388-396.

Maddieson, Ian (1993) "Splitting the mora". UCLA Working papers in Phonetics 93, 9-18.

Markus, Elena (2011) "The phonetics and phonology of a disyllabic foot in Soikkola Ingrian”. Linguistica Uralica 47, 2, 103-119.

Martinet, André (1949/1965) “La double articulation linguistique”. In André Martinet. La linguistique synchronique, 1-41. Paris: Presses Universitaires de France.

Mompéan-González, Jose Antonio (2014) “Cognitive linguistics and phonology”. In John Taylor and Jeannette Littemore, eds. The Bloomsbury companion to cognitive linguistics, 253-276. London and New York: Bloomsbury Academic.

Newman, Paul (1972) "Syllable weight as a phonological variable: the nature and function of the contrast between "heavy" and "light" syllables". Studies in African linguistics 3, 3, 301-323.

Odden, David (1997) "Some theoretical issues in Estonian prosody". In Estonian Prosody, 165-195. Tallinn.

Ojamaa, Koit (1976) Temporal aspects of phonological quantity in Estonian. Unpublished Doctoral Thesis. University of Connecticut.

Pajusalu, Karl (2009) "Dynamics of Estonian phonology”. STUF — Language Typology and Universals, Sprachtypologie und Universalienforschung 62, 109-121.

Pajusalu, Karl (2015) “Eesti vältesüsteemi olemusest”. Keel ja Kirjandus 4, 262-267.

Pajusalu, Karl, Toomas Help, Pärtel Lippus, Ellen Niit, Pire Teras, and Tiit-Rein Viitso (2005) "On the temporal structure of Estonian secondary-stressed feet". Linguistica Uralica 41, 2, 98-106.

Pike, Kenneth L. and Eunice Viktoria Pike (1947) "Immediate constituents of Mazateco syllables". International Journal of American Linguistics 13, 2, 78-91.

Plüschke, Mareike (2011) "Peak alignment in falling accents in Estonian". In Proceedings of the 17th International Congress of Phonetic Sciences (ICPhS XVII), Hong Kong, China, August 17-21, 2011, 1614-1617. Hong Kong: City University of Hong Kong. 
Plüschke, Mareike (2013) Peak alignment in Estonian. Unpublished Doctoral Thesis. München: Ludwig-Maximilians-Universität München.

Pöchtrager, Markus (2006) The structure of length. Unpublished Doctoral Thesis. Wien: Universität Wien.

Pöchtrager, Markus (2015) “Beyond the segment”. In Eric Raimy and Charles E. Cairns, eds. The segment in phonetics and phonology, 44-64. Wiley Blackwell.

Prillop, Külli (2011) Optimaalsusteoreetiline käsitlus eesti keele fonoloogilisest kujunemisest. (Diss. Phil. Estonicae Universitatis Tartuensis, 28.) Tartu: Tartu Ülikooli Kirjastus.

Prillop, Külli (2013) "Feet, syllables, moras and the Estonian quantity system". Linguistica Uralica 49, 1, 1-29.

Prillop, Külli (2015) "Hääliku-, silbi- ning jalavälde: ühe nähtuse mitu tähku”. Journal of Estonian and Finno-Ugric Linguistics 6, 3, 169-195.

Prillop, Külli (2018a) "Mida teeb moora eesti keeles". Keel ja Kirjandus 5, 345-364.

Prillop, Külli (2018b) "Varjatud muutused eesti keele prosoodilises struktuuris". Keel ja Kirjandus 6, 433-452.

Prince, Alan (1980) “A metrical theory for Estonian quantity”. Linguistic Inquiry 11, $511-562$.

Ross, Jaan and Ilse Lehiste (2001) The temporal structure of Estonian runic songs: a study of the relationship between language and music. Berlin: Mouton de Gruyter.

Schiering, René, Balthasar Bickel, and Kristine A. Hildebrandt (2010) "The prosodic word is not universal, but emergent". Journal of Linguistics 46, 3, 657-709.

Selkirk, Elisabeth O. (1980) "The role of prosodic categories in English word stress". Linguistic Inquiry 11, 563-605.

Selkirk, Elisabeth O. (1984) Phonology and syntax: the relation between sound and structure. Cambridge, MA, and London, England: MIT Press.

Trubetzkoy, Nikolai S. (1935/1968) Introduction to the principles of phonological descriptions. The Hague: Martinus Nijhoff.

Trubetzkoy, Nikolai S. (1939/1969) Principles of phonology. Berkeley and Los Angeles: University of California Press.

van der Hulst, Harry (2010) "Representing accent”. Phonological studies 13, 117-128.

van der Hulst, Harry (2014) "Representing rhythm". In Harry van der Hulst, ed. Word stress: theoretical and typological issues, 3-55. New York: Cambridge University Press.

Viitso, Tiit-Rein (1978) “Accents in Estonian”. Estonian Papers in Phonetics 1978, 94-98.

Viitso, Tiit-Rein (1979) "Problemy udarenija v èstonskom jazyke". Sovetskoe finno-ugrovedenie 15, 3, 136-152.

Viitso, Tiit-Rein (1982) “Morosčitajuščij li jazyk ėstonskij?”. Sovetskoe finno-ugrovedenie 8, 1, 8-20.

Viitso, Tiit-Rein (2003) "Structure of the Estonian language: phonology, morphology and word formation". In Mati Erelt, ed. Estonian language, 9-92. (Linguistica Uralica Supplementary Series,1.) Tallinn: Estonian Academy Publishers. 
Viitso, Tiit-Rein (2008) Liivi keel ja läänemeresoome keelemaastikud. Tartu and Tallinn: Eesti Keele Instituut.

Viks, Ülle (1992) A concise morphological dictionary of Estonian. Vol. 1: Introduction and grammar. Tallinn: Estonian Academy of Sciences.

Wiik, Kalevi (1982) "Viron äännekestojen sääntösynteesi”. Symposiumi 1982. Suomalais-neuvostoliittolainen itämerensuomalaisen filologian symposiumi 30.8-2.9.1982, Jyväskylä: Esitelmien refereaatit, 76-77. Jyväskylä: Jyväskylän yliopisto.

Wiik, Kalevi (1985) “Regelsynthese zur Lautquantität im Estnischen”. In Heikki Leskinen, ed. Ostseefinnische Untersuchungen. Ergebnisse eines Finnisch-Sowjetischen Symposions, 129-137. Helsinki: Suomalaisen kirjallisuuden seura.

Wiik, Kalevi (1991) "On a third time of speech rhythm: foot timing”. In Proceedings of the XIIth International Congress of Phonetic Sciences. Vol. 3, 298-301. Université de Provence.

Zalizn'ak, Andrej A. (1985). Ot praslav'anskoj akcentuacii k russkoj. Moskva: Nauka.

\begin{abstract}
Аннотация. Наталья Кузнецова: Эстонская словесная просодия в Прокрустовом ложе мор. Статья посвящена анализу существующих морных подходов к анализу количества в эстонском языке. Обсуждается основные особенности морных концепций эстонского количества в рамках функциональной и генеративной лингвистики, а также понимание моры фонетистами. Генеративные концепции совмещают на одном иерархическом уровне репрезентации (морном) нескольких разных с функциональной и структурной точки зрения пластов информации, что приводит к значительному усложнению формального описания и внутренним противоречиям. В рамках структурного функционального понимания эстонского количества моры могут служить вспомогательным средством для формализации просодической оппозиции краткого (легкого) и долгого (тяжелого) ударного слога. Релевантность этой оппозиции проявляется в функционировании просодической системы языка. Этот контраст надстраивается над сегментной оппозицией кратких и долгих фонем и, в свою очередь, формирует базис для оппозиции лексикализованных стопических акцентов, легкого и тяжелого. В качестве примера в статье приводится формальный морфонологический алгоритм присваивания стопических акцентов в словоформе и показано место в нем слогового веса.
\end{abstract}

Ключевые слова: эстонский, структурная функциональная фонология, автосегментная фонология, словесная просодия, мора, количество 
Kokkuvõte. Natalia Kuznetsova: Eesti sõnaprosoodia moorade Prokrustese sängis. Artiklis analüüsitakse eesti keele vältekontseptsioone, mis rakendavad mooralist analüüsi. Hinnatakse peamisi funktsionaalseid, generatiivseid ja foneetilisi moorasid arvestavaid seletusi eesti keele kohta. Enamasti esindavad generatiivsetes seletustes moorad samaaegselt mitut funktsionaalselt ja struktuuriliselt hajusa informatsiooni tasandit. See toob kaasa märkimisväärse formaalsete analüüsitehnikate keerustumise ja sisemised vastuolud. Strukturaal-funktsionaalses raamistikus saab moorasid kasutada eesti keeles pika ja lühikese rõhulise silbi prosoodilise kontrasti esitamiseks. Selle sobivust jälgitakse prosoodilise süsteemi tegeliku toimimise põhjal. Kontrast põhineb pika ja lühikese foneemi segmentaalsel kontrastil ja on omakorda aluseks kahele erinevale kõnetakti aktsendile, kergele ja raskele. Artiklis on näitena välja pakutud morfofonoloogiline algoritm eesti keele taktiaktsentide arvutamiseks, mis näitab ka silbikaalu kontrasti kohta.

Märksõnad: eesti keel, strukturaal-funktsionaalne fonoloogia, autosegmentaalne fonoloogia, sõnaprosoodia, moora, välted 